J. Range Manage.

55: 2-11 January 2002

\title{
Classifying federal public land grazing permittees
}

\author{
BRADLEY J. GENTNER AND JOHN A. TANAKA
}

Authors are Economist, National Marine Fisheries Service F/ST 1, 1315 East West Highway, Silver Spring, Maryland 20910, formerly graduate Research Assistant, Agricultural and Resource Economics, Oregon State University, and Associate Professor, Agricultural and Resource Economics, Oregon State University, Corvallis, Ore..

\begin{abstract}
This study identifies the characteristics and attitudes of public land ranchers. Data from a random survey of 2,000 U.S. Forest Service and Bureau of Land Management grazing permittees (53.5\% response rate) were cluster analyzed and 8 distinct groups of ranchers were identified. Each cluster differed with respect to why they were in ranching and how they would respond to public land policy changes related to grazing fees, grazing reductions, and changes in grazing season. Profit motivation for being in ranching was found to be a relatively low objective for all 8 types of ranchers.
\end{abstract}

Key Words: grazing fee, grazing reductions, grazing season, public land policy

Traditional uses of public land were established by a national policy of expansion in an effort to settle the west. Communities have since evolved dependent on traditional consumptive uses. These communities have strong ties to this traditional way of life and their culture reflects this tie. Despite efforts to settle the west, the federal government is the largest single landowner in the 11 western states. The Bureau of Land Management (BLM) and the United States Forest Service (USFS) administer the bulk of this public land that totals some $42 \%$ of the total land area in the region. Federal ownership by state varies from $22 \%$ in Washington to $77 \%$ in Nevada. The BLM and the USFS manage these lands to provide timber, grazing, recreation and mineral production, among other goods and services.

Approximately $85 \%$ of federal land is grazed by domestic livestock (CAST 1996). The 2 management agencies administer 29,925 grazing permits across the west. These permits cover approximately 21.6 million federal animal unit months (AUMs) of grazing (CAST 1996). Grazing permit holders account for over half of the commercial beef cattle in these 11 western states (CAST 1996). Levels of yearlong dependence on public forage vary across the West: some ranches utilize federal lands for a

The authors would like to thank the USDA Fund for Rural America for funding this research through the grant "Western Regional Evaluation of Social and Economic Impacts of Public Land Policy." We would also like to thank members of Western Regional Research Project 192, "Rural Communities and Public Lands in the West: Impacts and Alternatives" for reviewing survey drafts and providing boundless support. We would especially like to thank the public land ranchers who took the time to fill out and return the survey form.

Oregon State Agricultural Experiment Station Technical Paper Number 11753

Manuscript accepted 19 March 01

\section{Resumen}

El objetivo fue estudiar las características productivas y las expresiones de pensamiento de los productores que explotan terrenos comunales federales. Los datos fueron obtenidos por encuestas aleatorias de $\mathbf{2 0 0 0}$ permisionarios del Servicio Forestal y de la Fauna, y de la Oficina de Manejo de los Suelos. El análisis de las encuestas permitió la formación de ocho diferentes grupos de productores con caracteristícas comunes. La diferencia entre los grupos se basó en las motivos particulares por los cuales ellos estan produciendo en los terrenos comunales federales y el impacto que tienen los cambios en las politícas del manejo de terrenos comunales federales relacionados con las cuotas de pastoreo, la reduccón de las areas de apacentamiento y los cambios en las estaciones de pastoreo sobre la rentabilidad financiera global de la explotaciones. Los resultados indicaron que la ganancia monetaria no es el objetivo principal de los productores que explotan terrenos comunales federales.

large part of their seasonal grazing capacity and some ranches, in areas where yearlong grazing is possible, depend on federal lands for most, if not all, AUMs of grazing capacity.

In recent times, the use of public lands for non-consumptive uses, such as recreation and preservation, has increased dramatically. In the 1980 s, visitor days on USFS lands increased by approximately 50\% (CAST 1996). Also, some individuals that don't actively use public land have become advocates of preservation of these lands for environmental reasons. These 2 new and growing groups are typically from urban areas and are much more active and vocal than urbanites from the past regarding rural land use matters. Generally, these new activists feel nonconsumptive resource uses, such as recreation and preservation, should be given higher weight than consumptive uses such as grazing, timber production and mining when decisions are made concerning public land management. Specifically, these new activists feel that the grazing of public lands is a destructive use governed by obsolete policies serving narrow economic interests (Power 1996). These activists feel that the ranching way of life is subsidized through low grazing fees and government supplied range and water improvement practices. Activists also feel that the shift to non-consumptive uses will not cause the collapse of communities built on traditional uses, as recreation and other service industries will make up for the losses from elimination of traditional uses (Power 1996). As a result, public land management decisions today are usually hotly contested by new activists. Additionally, these new activists have become strong advocates for changes in our existing public land policies. 


\section{Conceptual Framework}

Changing land management paradigms means changing the allocation of economic resources on regional and local levels. In addition, changing public land grazing policies will impact the social and cultural importance of public lands to local communities. When policies are considered with such broad ranging impacts, these decisions should be made with due care.

To assist policy makers in making these difficult policy choices, ranch, community, and local/regional level impacts of policy changes need to be analyzed in a scientific manner. Assessing impacts involves many layers of information and many procedures. Individuals affected by policy changes must be identified and defined in a way that is relevant to the situation. This becomes difficult when dealing with western public land ranchers because it has been suggested that ranchers are very heterogeneous. Both Workman (1986) and Fowler and Gray (1988) speak of the heterogeneity of ranchers. Fowler and Gray (1988) call it the "double infinity" of ranching. The first infinity arises from the wide array of physical variation existing across western grazing lands. The second infinity stems from the different institutional and social aspects of ranchers. Rancher characteristics, such as managerial ability, skill, and knowledge vary widely across the West. Because of this heterogeneity, the typical production function approach has been difficult to apply to the ranching industry. Fowler and Gray (1988) concluded that efforts should be made to categorize the diverse population of ranchers so that progress can be made in this direction.

In the 1970s, Arizona ranches had return rates that ranged from negative to $1-2 \%$, while prices for ranches seemed well above a "rational value" based on the capitalized value of ranch earning potential (Smith and Martin 1972). Arizona ranch prices remained constant between 1961 and 1971, maintaining an unexplained, almost constant opportunity cost above a ranch's value in use (Smith and Martin 1972). These results are supported for small, medium, and large ranches across the west (Harper and Eastman 1980, Young and Shumway 1991, Fowler and Gray 1988, Workman 1986). This suggests that profit maximization is not the primary goal of public land ranchers. Instead, Smith and Martin (1972) suggested that the theory of economic satisficing is more applicable in the case of the western ranchers. This framework allows for a whole range of desired returns, or levels of profit preference, across the popula- tion of all public land ranchers, further supporting a high degree of heterogeneity in the population of ranchers west-wide.

The objective of this paper is to define subgroups of public land ranchers based on a continuum of management goals from economic satisficing to strict profit maximization. Past research has led to the conclusion that the goals and objectives of these ranchers vary across these subgroups. Because all public land ranchers cannot be broadly categorized under the classical profit maximizing assumption, policies crafted and decisions made based on economic analyses using this assumption will not provide the desired outcomes. Specifically, a household production function approach would be more appropriate for ranchers on the consumptive side of this continuum while a more typical production function approach would be more appropriate for ranchers on the profit oriented end of the continuum. By defining the subgroups of this population and modeling their behavior based on their place on the continuum, informed choices can be made based on the attributes of the sub-group the policy is targeted towards, providing more effective solutions to today's complex and controversial public land management decisions.

\section{Cluster Analysis}

Cluster analysis identifies natural groupings within a mixture of observations that are believed to represent several distinguishable populations (Lorr 1983). Rosenburg and Turvey (1991) go on to add that cluster analysis includes a set of methods that apply "exploratory techniques to an initially unclassified data set to discover the underlying categorical structure and to establish a categorization scheme that allows a mathematical-statistical interpretation or results." The cluster analysis process is comprised of a series of steps (Aldenderfer and Blashfield 1984, Romesburg 1984) detailed below.

\section{Selection of Observational Units}

The observational units, public land permittees, to be categorized must be selected. In this case, public land permittees are the observational units. Because basic socioeconomic and demographic data for federal land grazing permittees were not available from a published data source, a survey of the population federal land grazing permittees was conducted. A comprehensive list of all permittees was obtained from both the USFS and the BLM. According to these lists, 29,925 grazing permits were issued in 1998. Address duplicates, cross agency duplicates, and institutional permits were culled from the population leaving 21,018 individual ranch operators.

A random sample of 2,000 operators was drawn from the population and mailed surveys based on Salant and Dillman's (1994) Revised Total Design Method (RTDM). We used a series of 4 mailings spread over the course of 8 weeks. If the respondent left less than 3 items blank, those respondents were kept and missing values were imputed from the rest of the data. The useable response rate for the survey is $53.5 \%$. Figure 1 shows the proportion of the total population and the survey respondents from each state. The "other" category includes respondents from 37 different states. A follow-up telephone sur-

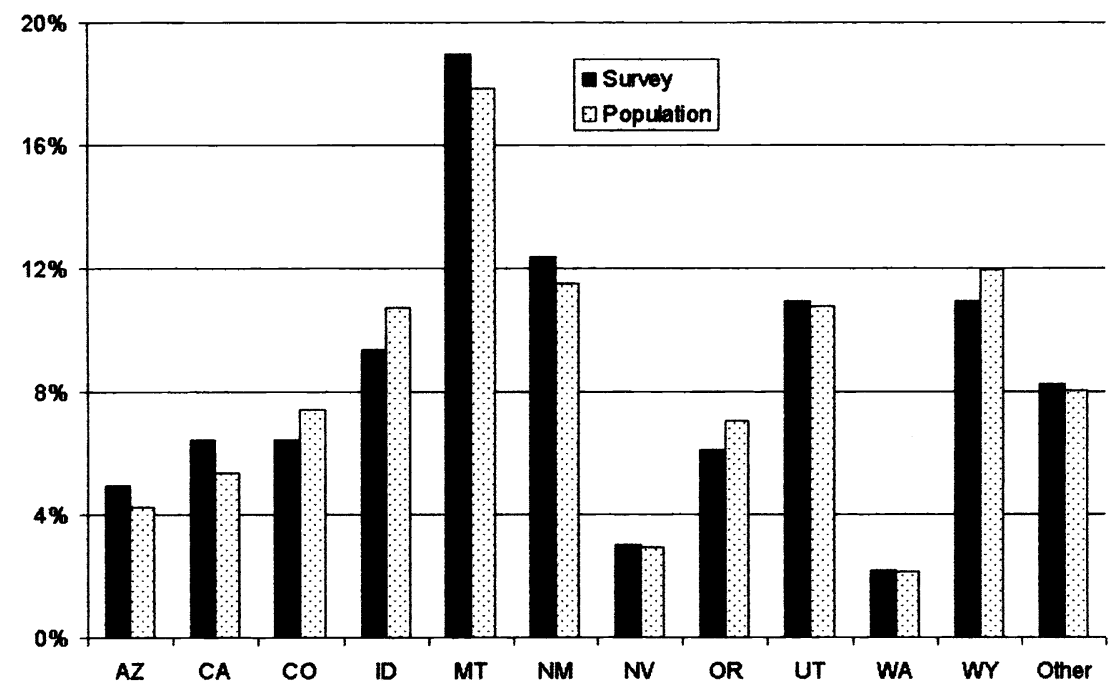

Fig. 1. Percent of the population and survey respondents from each state. 
vey of 100 randomly selected non-respondents revealed that the means of several key demographic characteristics were not significantly different between respondents and non-respondents. Therefore, the data presented can be interpreted to accurately represent the population of all public land permittees.

\section{Selection of Rancher Attributes}

The variables, or attributes, within each observational unit to be clustered must be selected based on explicitly stated theory that supports classification (Aldenderfer and Blashfield 1984). Drawing from previous literature, ranchers appear to maximize a utility function composed of profit and many other attributes. Perceived goals and objectives are strongly tied to whether or not profit maximization is the primary goal for continuing in ranching. Both Bartlett et al. (1989) and Smith and Martin (1972) used a survey method to elicit the reasons public land ranchers continued ranching in the West. Ranchers were asked to rank the importance of many goals and objectives that ranged from profit motivated objectives to lifestyle objectives. The same methodology was used for this analysis. The list of goals and objectives used in this analysis grew out of Bartlett et al.'s (1989) and Smith and Martin's (1972) work. In addition, focus group interviews in Oregon and New Mexico were used to hone the list into 7 goals and objectives for continuing ranching. These goals are listed below with attribute names in parentheses:

1. Owning land and a ranch is consistent with my family's tradition, culture, and values (TRAD).

2. A ranch is a good place to raise a family (FAMILY).

3. Living on a ranch allows me to live closer to my friends and family (FRIEND).

4. I want to obtain a good return on my investment (PROFIT).

5. With my skills it would be difficult to obtain a job outside of the ranch (SKILLS).

6. I own a ranch primarily for environmental purposes (ENVIRO).

7. I continue ranching so I will have a business to pass on to my children (PASS).

The respondents were asked to rank the importance of each objective on a scale of 1 to 5, with 1 being the most important.

Much past work has shown that as dependence on agricultural income increases, the likelihood that the farmer or rancher is a profit maximizer increases
(Young and Shumway 1991, Smith and Martin 1972, Biswas et al. 1984, Harper and Eastman 1980, and Birkenfeld 1994). Conversely, the lower the dependence on agricultural income, the more likely an agricultural producer will be in the industry for consumptive reasons (Smith and Martin 1972, Biswas et al. 1984, Harper and Eastman 1980, and Birkenfeld 1994). For these reasons, income from different sources will be used as a clustering attribute. Ranchers were asked the percentage of their total income coming from the following sources (variable names in parentheses): ranching (RANCH), production of other agricultural commodities (AGRI), forestry (FOREST), off-farm job (OFFRNCH), retirement income (RETIRE), investment income (INVST), providing on-ranch recreation services (REC), and other sources (OTHERC). It is thought that there may be an additional difference in operators that ranch for consumptive purposes. Some may be retired hobbyists and others may be hobbyists that are still working a full time job outside of the ranch (Birkenfeld 1994). Because categorical variables cannot be mixed with quantitative variables for cluster analysis (Everitt 1993), these percent income variables were converted to categorical responses using 6 categories $(<5 \%$, $6 \%-25 \%, \quad 26 \%-50 \%, \quad 51 \%-75 \%$, $76 \%-95 \%,>96 \%)$

Labor and education have been used to describe differences in management objectives (Young and Shumway 1991, Smith and Martin 1972, Biswas et al. 1984, Harper and Eastman 1980, and Birkenfeld 1994). Ranchers were asked how many months of full time and part time labor were supplied by themselves, their spouse, their children and hired employees. These variables were transformed into full time months and combined into 2 variables FAM and HIRED representing the number of months of family supplied labor and the number of months of hired labor required to run their operation. It is thought that small ranchers on the consumptive end of the scale will have the smallest labor requirements, hiring few laborers and supplying small amounts of family labor. Medium sized ranchers that depend on most of their income from ranching will have the most family supplied labor, but will not hire many employees. Also, large ranchers that have little income from off ranch sources will depend heavily on hired labor while the family supplied component will be small relative to the hired portion.

The effect of education is slightly less transparent. Typically, as the level of edu- cation increases, the likelihood that the individual is operating as a profit maximizer also increases. However, it is hypothesized that some hobbyists parttime ranchers may be highly educated business professionals who own a ranch for consumptive purposes, and do not function as strict profit maximizers. In this case, education may play a slightly different role in developing clusters.

Operation scale has also been shown to explain choice of management goals. The larger the operation, the more likely the goal of profit maximization supercedes all other goals (Young and Shumway 1991, Smith and Martin 1972, Biswas et al. 1984, Harper and Eastman 1980, and Birkenfeld 1994). The survey provides 2 possible scale variables, deeded acres and herd size across three animal types. Herd size across 3 animal types will be used as the scale variable over deeded acreage because land productivity varies greatly over the West and herd size describes scale in more absolute terms by controlling for land quality. The respondents were asked to circle a category indicating the number of cows, ewes, and horses they own. The categories included $0,1-49$, 50-99, 100-249, 250-499, 500-999, and greater than 999 animals. These categories represent accepted size classes in ranch management (Workman 1986).

Finally, respondents were asked to characterize the business organization of their ranch. Choices included sole proprietorship, limited partnership, general partnership, sub-chapter S-corporation, sub-chapter C-corporation, and Limited Liability Company. Each type of organizational structure offers protection from financial risk of varying degrees. One would expect that profit maximizing firms would choose to organize their ranch in a fashion that provided the most protection and that ranchers most interested in consumptive values would have little reason to pursue organizational structures more complicated than sole proprietorship. For these reasons, level of business organization was included. Two other variables that help explain risk preparedness and degree of profit maximization include debt load and financial stress. For debt load, one would expect those with high debt loads to be more concerned about the returns from ranching and vice versa. Respondents were asked to give the percentage of ranch sale price retained, if they were to sell their ranch, and were presented with 4 responses that include: $<5 \%, 5 \%-29 \%$, $30 \%-59 \%, 60 \%-100 \%$, as taken from the USDA's Farm Cost and Return Surveys 
(USDA 1993). Finally, financial stress was used as an indicator of a respondent's ability to obtain loans. The response was limited to a Likert scale with 1 representing severe financial stress and 5 representing no stress. It is thought that those involved in ranching for consumptive use will express a low degree of stress while those involved in ranching for profit will exhibit higher degrees of stress related to their debt load and other financial factors.

\section{Selection of the Clustering Algorithm}

The clustering algorithm computes similarities among observational units and differentiates observational units into subgroups. We used a K-means algorithm, a non-parametric method, that uses a Euclidean distance similarity measure and iterative partitioning to differentiate observational units into sub-groups or clusters. $\mathrm{K}$-means clustering requires that the number of clusters be established a priori (Bernhardt et al. 1996). Procedures used to find a local partition optimum, based on the a priori selection of the optimum number of partitions, are heuristic and can be described mathematically as follows:

Minimize:

$$
e[P(M, K)]=\sum_{\mathrm{i}=1}^{m} D\left[\mathrm{i}, L_{k i}\right]^{2}
$$

Subject to:

$$
D(i, L)=\left[\sum _ { j = l } ^ { j } \left[A(i j)-B(L j]^{2} \text { for all } \mathrm{K}\right.\right.
$$

where $\mathrm{D}(\mathrm{i}, \mathrm{L})$ is the Euclidean distance between the $i^{\text {th }}$ observation and the cluster mean of the $\mathrm{L}^{\text {th }}$ cluster, and $\mathrm{e}[\mathrm{P}(\mathrm{M}, \mathrm{K})]$ is the error of partition. The letter $\mathrm{i}$ indexes observations from 1 to $\mathrm{M}, \mathrm{j}$ indexes the attributes from 1 to $\mathrm{J}$, and $\mathrm{L}_{\mathrm{Ki}}$ is cluster $\mathrm{K}$ containing the $i^{\text {th }}$ observation. Additionally, $A(i, j)$ equals the value of the $i^{\text {th }}$ observation of the $\mathrm{j}^{\text {th }}$ attribute and $\mathrm{B}(\mathrm{L}, \mathrm{j})$ is the mean of the $\mathrm{j}^{\text {th }}$ attribute of observations in the $\mathrm{L}^{\text {th }}$ cluster. $\mathrm{P}(\mathrm{M}, \mathrm{K})$ is the partition composed of $\mathrm{K}$ clusters where each of the $\mathrm{M}$ observations lie in 1 of the $\mathrm{K}$ clusters..

Attributes are first sorted according to their distance from the overall attribute mean. Initial centroids are then chosen based on $\left[1+\left(\mathrm{L}_{\mathrm{K}}{ }^{-1}\right) \cdot \mathrm{M} / \mathrm{K}\right]$ observations. Given the above, the algorithm searches for the partition with the smallest $\mathrm{e}[\mathrm{P}(\mathrm{M}, \mathrm{K})]$. Iterations stop when $\mathrm{e}[\mathrm{P}(\mathrm{M}, \mathrm{K})]$ cannot be reduced further. Beginning with the initial partition, each observation, $i$, is transferred from its current cluster $\mathrm{L}_{\mathrm{Ki}}$ into every other cluster $\mathrm{L}_{\mathrm{K}}$, where $\mathrm{K} \neq \mathrm{i}$. If at least 1 cluster has a Euclidean distance less than $\mathrm{D}\left(\mathrm{i}, \mathrm{L}_{\mathrm{K}}\right)$, the observation i is transferred to that cluster. Transferring all $\mathrm{M}$ observations continues until e $[\mathrm{P}(\mathrm{M}, \mathrm{K})]$ is minimized across all partitions. This procedure was conducted using the FASTCLUS procedure in SAS (SAS 1989). Local optimums are found by iteratively running the $\mathrm{K}$-means algorithm, each time with a different number of clusters. This analysis followed the SAS Institute's recommendation, running the algorithm beginning at 2 clusters and continuing through $10 \%$ of the total number of observations in the data set (SAS 1989).

\section{Solution Validation}

The final step in cluster analysis involves testing the validity of the analysis. First, the number of clusters must be determined. This can pose problems, as analytical determination of the number of clusters for a given data set is not definitive. However, several indices can serve as guides (Jain and Dubes 1988). The ratio of the within sum of squares for the cluster grouping being analyzed to the within sum of squares for 1 group is 1 appropriate index (Bernhardt et al. 1996). In other words, this index is the percent of total variation in all variables not accounted for by clustering (Bernhardt et al. 1996). Another, more rigorous index is the Cubic Clustering Criterion (CCC) (SAS 1983). This index is based on minimizing the within cluster sum of squares. This index can also be a good diagnostic tool. Peaks greater than 2 or 3 indicate good clusters (SAS 1983). Very negative values of the CCC indicate outliers in the data (SAS 1983). Very distinct non-hierarchical spherical clusters usually show a sharp rise to the peak number of clusters with a

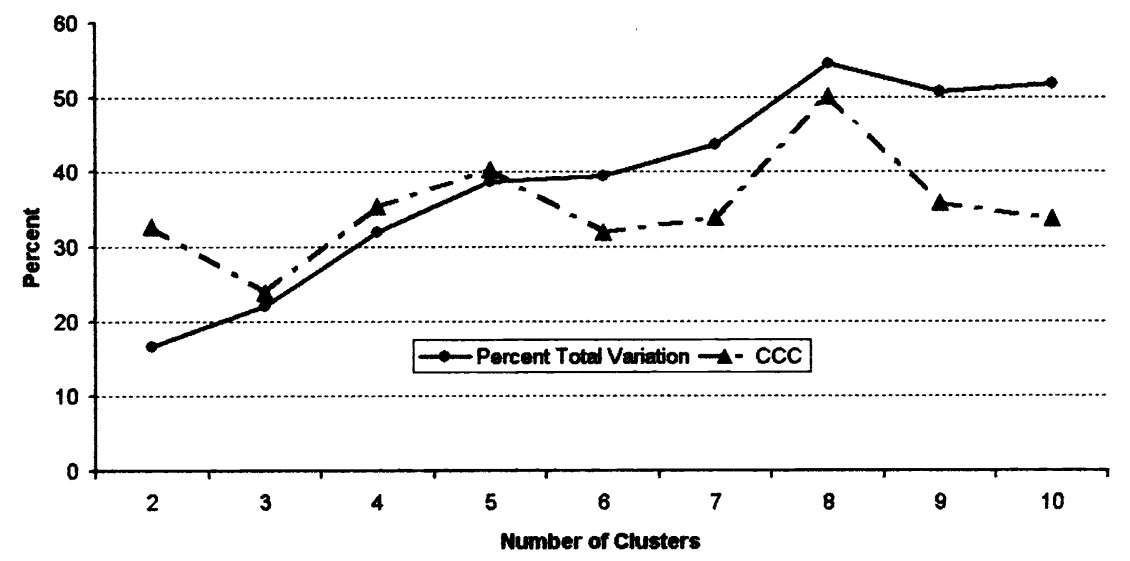

Fig. 2. Optimum Cluster cluster Comparison comparison using the percent of total variation in all variables not accounted for by clustering and the Cubic Clustering Criterion (CCC) methods. gradual decline thereafter (SAS 1983). Graphing these indices on the number of cluster groups can identify the appropriate number of clusters. The appropriate number of clusters can be identified by graphing the index on the number of cluster groups. The point where the slope of this these graphs begins to drop dramatically indicates the appropriate number of groups. This occurs where the within sum of squares for the cluster grouping is reduced very little by the addition of another cluster group (Jain and Dubes, 1988) (SAS 1983).

Looking at Figure 2, these indices show that we have good, non-hierarchical, spherical clusters, with no outliers, and local optimums at both 5 and 8 clusters. Unfortunately, within FASTCLUS there is no method within FASTCLUS to test whether the 5-cluster solution is better than the 8-cluster solution. The 8-cluster solution appears better because 8 clusters describe $15.7 \%$ more variation. Because this method is not definitive, qualitative judgments also count. Rosenburg and Turvey (1991) suggested that the appropriate number is simply the number that fulfills the objectives of the study. After looking at the means of the attributes across clusters, 8 clusters provide a better, more explicit set of rancher subgroups than 5 clusters.

Because choice of clustering method, attributes, and number of clusters is inexact, the validation process is very important. Aldenderfer and Blashfield (1984) provide descriptions of the various tests while Jain and Dubes (1988) provided in depth technical coverage. Two tests will be used in this analysis: a significance test on attributes used to create clusters and a sig- 
Table 1. Clustering attribute means by cluster groups.

\begin{tabular}{|c|c|c|c|c|c|c|c|c|c|}
\hline \multirow[b]{3}{*}{ Clustering attribute } & \multicolumn{8}{|c|}{ Cluster Groups $^{1}$} & \multirow[b]{3}{*}{ p-value ${ }^{7}$} \\
\hline & \multicolumn{4}{|c|}{ Hobbyists } & \multicolumn{4}{|c|}{ Professionals } & \\
\hline & $\begin{array}{c}\text { Small } \\
\text { Hobbyist } \\
(n=117)\end{array}$ & $\begin{array}{c}\text { Retired } \\
\text { Hobbyist } \\
(\mathrm{n}=189)\end{array}$ & $\begin{array}{l}\text { Working } \\
\text { Hobbyist } \\
(\mathrm{n}=162)\end{array}$ & $\begin{array}{l}\text { Trophy } \\
\text { Rancher } \\
(\mathrm{n}=63)\end{array}$ & $\begin{array}{l}\text { Diversified } \\
\text { Family } \\
\text { Rancher } \\
(\mathrm{n}=142)\end{array}$ & $\begin{array}{l}\text { Dependent } \\
\text { Family } \\
\text { Rancher } \\
(\mathrm{n}=196)\end{array}$ & $\begin{array}{l}\text { Corporate } \\
\text { Rancher } \\
(\mathrm{n}=138)\end{array}$ & $\begin{array}{l}\text { Sheep } \\
\text { Rancher } \\
(\mathrm{n}=45)\end{array}$ & \\
\hline \multicolumn{10}{|l|}{ Objectives $^{2}$} \\
\hline TRAD & 3.7 & 4.6 & 4.5 & 3.4 & 4.1 & 4.9 & 4.5 & 4.4 & \\
\hline FAMILY & 3.7 & 4.6 & 4.6 & 3.3 & 4.2 & 4.9 & 4.5 & 4.5 & 0.0001 \\
\hline FRIEND & 2.8 & 3.9 & 3.5 & 2.1 & 2.9 & 4.4 & 3.5 & 3.2 & 0.001 \\
\hline PROFIT & 2.6 & 3.7 & 3.6 & 2.6 & 3.7 & 4.2 & 3.6 & 3.5 & 0.0001 \\
\hline SKILLS & 1.5 & 2.3 & 1.8 & 1.3 & 2 & 3.3 & 2.3 & 2.3 & 0.001 \\
\hline ENVIRO & 2.4 & 2.2 & 2.3 & 2.1 & 1.9 & 2.3 & 2 & 2 & 0.001 \\
\hline PASS & 1.5 & 4.3 & 4 & 2.4 & 2.3 & 4.8 & 4.1 & 3.8 & (NS) \\
\hline \multicolumn{10}{|l|}{ Education $^{3}$} \\
\hline Did no finish HS & 5.1 & 11.1 & 3.1 & 0 & 4.2 & 16.8 & 3.6 & 6.7 & 0.001 \\
\hline Graduated HS & 16.2 & 23.3 & 25.3 & 6.3 & 25.4 & 44.9 & 14.5 & 11.1 & \\
\hline Some college & 28.2 & 36.5 & 40.7 & 22.2 & 45.1 & 30.6 & 40.6 & 35.6 & \\
\hline 4 year degree & 22.2 & 15.9 & 21.6 & 44.5 & 21.1 & 6.1 & 38.4 & 44.4 & \\
\hline Graduate degree & 28.2 & 13.2 & 9.3 & 27 & 4.2 & 1.5 & 2.9 & 2.2 & \\
\hline \multicolumn{10}{|c|}{ Business Organization ${ }^{3}$} \\
\hline Sole proprietor & 70.1 & 66.7 & 69.1 & 22.2 & 80.3 & 65.3 & 9.4 & 378 & 0.001 \\
\hline General partner. & 18.8 & 17.9 & 15.4 & 9.5 & 9.2 & 20.4 & 8.7 & 20 & \\
\hline Limited partner. & 4.3 & 15.3 & 11.7 & 6.3 & 4.2 & 19.4 & 11.6 & 11.1 & \\
\hline S. corp. & 4.3 & 10.6 & 1.9 & 33.4 & 4.2 & 9.7 & 36.2 & 15.6 & \\
\hline C. corp. & 0.9 & 0 & 1.2 & 12.7 & 1.4 & 3.6 & 20.3 & 4.4 & \\
\hline LLC & 1.7 & 1.6 & 0.6 & 15.9 & 0.7 & 1 & 13.8 & 11.1 & \\
\hline \multicolumn{10}{|l|}{ \# of Animals ${ }^{4}$} \\
\hline Cows & 79.5 & 122 & 143 & 466.7 & 276.2 & 295.7 & 615.2 & 385.8 & 0.001 \\
\hline Ewes & 27.5 & 4.4 & 10.1 & 0.8 & 7.8 & 10.6 & 3.1 & 796 & 0.001 \\
\hline Horses & 17 & 21.5 & 20.3 & 28.6 & 20.9 & 20.6 & 26.1 & 24.4 & 0.001 \\
\hline \multicolumn{10}{|l|}{ Labor } \\
\hline FAM & 10.5 & 17.2 & 14.9 & 13.5 & 20.7 & 24.6 & 26.7 & 27.5 & 0.001 \\
\hline HIRED & 4.5 & 4.8 & 2.3 & 28.2 & 4.3 & 3.6 & 32 & 45.3 & 0.001 \\
\hline \multicolumn{10}{|l|}{ Income } \\
\hline RANCH & 13 & 21.5 & 18.2 & 21.1 & 74.9 & 84.7 & 71.9 & 80.8 & 0.001 \\
\hline AGRI & 2.3 & 15.3 & 1.9 & 6.9 & 7.4 & 5 & 7.1 & 1.4 & 0.001 \\
\hline FOREST & 2.2 & 6.1 & 0.4 & 0.8 & 3 & 1 & 2.1 & 0.7 & 0.001 \\
\hline OFFRNCH & 57.2 & 5.1 & 77.4 & 15.7 & 7.6 & 4.8 & 9.2 & 6.2 & 0.001 \\
\hline RETIRE & 12.9 & 36.5 & 0.5 & 9.1 & 1.4 & 2.5 & 2.6 & 0.7 & 0.001 \\
\hline INVST & 11.7 & 8.8 & 1.2 & 40.7 & 3.2 & 1.4 & 3.3 & 7.1 & 0.001 \\
\hline REC & 1.5 & 2.8 & 0.3 & 3.7 & 1.2 & 0.2 & 2.3 & 1 & (NS) \\
\hline OTHER & 0.3 & 3.1 & 0.1 & 1.4 & 1 & 0.3 & 1.4 & 2 & 0.009 \\
\hline Debt Load ${ }^{5}$ & 3.7 & 3.5 & 3.3 & 3.8 & 3.4 & 3.3 & 3.4 & 3.4 & 0.001 \\
\hline Financial Stress ${ }^{6}$ & 3.5 & 2.9 & 2.5 & 3.2 & 2.4 & 4.5 & 2.3 & 2.3 & 0.001 \\
\hline $\begin{array}{l}23 \text { percent of total vari } \\
2 \text { Average Likert scale s } \\
3 \text { Represents percentage } \\
4 \text { Means based on midpo } \\
5 \text { Migh debt load, } 4= \\
61 \text { = hist } \\
7 \text { = severe financial str } \\
7 \text { Probability of obtainin } \\
\text { nificant }(\text { NS) if greater }\end{array}$ & $\begin{array}{l}\text { tecting each } \\
\text { ts of response } \\
\text { sw debt load. } 5=\text { low fin } \\
\text { Pearson's chi }\end{array}$ & $\begin{array}{l}\text { accounted } \\
\text { rtant, } 5=\mathrm{m} \\
\text { zory. } \\
\text { egories. } \\
\text { ed on USD } \\
\text { al stress. } \\
\text { are statistic }\end{array}$ & $\begin{array}{l}\text { e cluster gi } \\
\text { ortant reaso }\end{array}$ & tinuing t & & & & & \\
\hline
\end{tabular}

nificance test on the external indicator attributes. The first type of significance test is Pearson's chi-squared test of independence between each variable cluster analyzed and the cluster groups revealed. This procedure tests which variables are significant in explaining the variation across all cluster groups. The null hypothesis is independence between cluster attributes and cluster groups.

The external variable test, on the other hand, directly tests the generality of the cluster solution against the relative criteria. Aldenderfer and Blashfield (1984) suggested that cluster solutions passing this test are better than those that don't. Indicator attributes are those attributes that "represent characteristics of other hierarchical levels especially the socio-economic subsystem" (Bernhardt et al. 1996). Within this survey, those attributes include age, number of social organizations respondent is involved in, animal production system, income, family tenure (HIS-
TORY), deeded acres, environmental attitude score (ENVSCOR), conservation participation score (PARTSCOR), and seasonal dependence on public forage. The null hypothesis is independence between cluster attributes and cluster groups. A strong cluster solution should strongly reject this hypothesis. Finally, multivariate analysis of variance (MANOVA) can be used to test whether the vector of indicator means is different across groups (Bernhardt et al. 1996). The null hypothe- 
Table 2. Means of external indicator attributes by cluster.

\begin{tabular}{|c|c|c|c|c|c|c|c|c|c|}
\hline \multirow[b]{3}{*}{$\begin{array}{l}\text { External } \\
\text { Indicator } \\
\text { Attribute }\end{array}$} & \multicolumn{8}{|c|}{ Cluster Groups ${ }^{1}$} & \multirow[b]{3}{*}{ p-value ${ }^{7}$} \\
\hline & \multicolumn{4}{|c|}{ Hobbyists } & \multicolumn{4}{|c|}{ Professionals } & \\
\hline & $\begin{array}{c}\text { Small } \\
\text { Hobbyist }\end{array}$ & $\begin{array}{c}\text { Retired } \\
\text { Hobbyist }\end{array}$ & $\begin{array}{l}\text { Working } \\
\text { Hobbyist }\end{array}$ & $\begin{array}{l}\text { Trophy } \\
\text { Rancher }\end{array}$ & $\begin{array}{c}\text { Diversified } \\
\text { Family } \\
\text { Rancher }\end{array}$ & $\begin{array}{c}\text { Dependent } \\
\text { Family } \\
\text { Rancher }\end{array}$ & $\begin{array}{l}\text { Corporate } \\
\text { Rancher }\end{array}$ & $\begin{array}{c}\text { Sheep } \\
\text { Rancher }\end{array}$ & \\
\hline & ------------ & 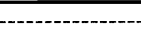 & $\ldots \ldots$ & $-\ldots---$ & ins) ----------- & ------------- & $\ldots \ldots$ & -...... & \\
\hline Age (years) & 57.46 & 64 & 51.27 & 59.02 & 53.85 & 61.05 & 55.61 & 57.8 & 0.001 \\
\hline Social Organizations ${ }^{1}$ & 2.53 & 2.78 & 2.77 & 3 & 2.77 & 2.44 & 3.15 & 3.13 & (NS) \\
\hline \multicolumn{10}{|l|}{ Production System ${ }^{2}$} \\
\hline Cow-calf & 67 & 71.6 & 70.6 & 71 & 73.9 & 68.8 & 529 & 43.2 & 0.001 \\
\hline Cow-calf-yearling & 10.4 & 14.8 & 21.3 & 21 & 20.4 & 28.6 & 42.8 & 13.6 & \\
\hline Stocker & 3.5 & 3.8 & 1.9 & 4.8 & 2.1 & 1 & 4.3 & 2.3 & \\
\hline Sheep & 6.1 & 1.1 & 1.9 & 0 & 0 & 1 & 0 & 38.6 & \\
\hline Horse & 7 & 4.4 & 2.5 & 0 & 2.8 & 0.5 & 0 & 0 & \\
\hline Other & 6.1 & 4.4 & 1.9 & 3.2 & 2.8 & 0 & 0 & 2.3 & \\
\hline Income $(\$) 1$ & 65,857 & 44,602 & 53,491 & 94,245 & 42,970 & 46,926 & 50,116 & 53,000 & 0.001 \\
\hline History (years) ${ }^{3}$ & 22.39 & 29.23 & 36.86 & 13.25 & 35.33 & 29.49 & 32.99 & 32.02 & 0.001 \\
\hline Deeded Acres & 1,398 & 2,620 & 1,563 & 11,134 & 4,765 & 4,058 & 12,554 & 14,849 & 0.001 \\
\hline Envscore $^{4}$ & 3.22 & 3.06 & 3.13 & 3.05 & 2.96 & 3 & 3.02 & 3.03 & (NS) \\
\hline Partscore $^{5}$ & 2.97 & 2.78 & 2.99 & 2.99 & 2.85 & 2.6 & 2.84 & 3 & 0.206 \\
\hline $\begin{array}{l}\text { Spring } \\
\quad \text { Dependency }(\%)^{6}\end{array}$ & 17.22 & 19.74 & 28.23 & 17.93 & 23.44 & 25.29 & 21.4 & 29 & 0.001 \\
\hline $\begin{array}{l}\text { Summer } \\
\quad \text { Dependency }(\%)^{6}\end{array}$ & 42.28 & 43.69 & 51.03 & 36.5 & 50.15 & 51.14 & 45.84 & 51.18 & 0.01 \\
\hline $\begin{array}{l}\text { Fall Dependency }(\%)^{6} \\
\text { Winter }\end{array}$ & 31.38 & 26.84 & 37.2 & 24.35 & 32.1 & 34.34 & 30.94 & 35.64 & 0.002 \\
\hline Dependency $(\%)^{6}$ & 14.19 & 13.76 & 20.44 & 25.03 & 10.27 & 14.01 & 13.43 & 32.84 & 0.002 \\
\hline $\begin{array}{l}2 \text { Means based on midpoin } \\
2 \text { Represents percentage se } \\
3 \text { History = respondent's f } \\
4 \text { Average Likert scale imp } \\
5 \text { Average Likert scale par } \\
6 \text { Percent dependency on } \\
7 \text { Probability of obtaining }\end{array}$ & $\begin{array}{l}\text { nts of respons } \\
\text { electing each } \\
\text { amily tenure } \\
\text { portance of } 8 \\
\text { ticipation sco } \\
\text { public forage } \\
\text { Pearson's ch }\end{array}$ & $\begin{array}{l}\text { categories. } \\
\text { tegory. } \\
\text { personal tenur } \\
\text { nvironmental } \\
\text { 1=not willin } \\
\text { urces by seas } \\
\text { square statistic }\end{array}$ & $\begin{array}{l}\text { ars. } \\
\text { gh debt load } \\
\text { rticipate, } 5= \\
\text { sting indepe }\end{array}$ & $\begin{array}{l}\text { w debt load } \\
\text { to particip } \\
\text { between } \mathrm{c}\end{array}$ & $\begin{array}{l}\mathrm{d} \text { on USDA de } \\
6 \text { riparian conse } \\
\text { grouping and } \mathrm{r}\end{array}$ & $\begin{array}{l}\text { d categories.i } \\
\text { on practices. }\end{array}$ & $1=$ not impo & $5=$ very impc & \\
\hline
\end{tabular}

sis is no difference between cluster groups and rejection of this null would strengthen the validity of the cluster solution.

Of the 24 attributes used to form the clusters, only 2, the PASS objective and the percentage of income from the provision of recreation services, proved insignificant. Table 1 presents the means of the attributes by cluster and the significance test on each variable. Of the 12 external indicator attributes (Table 2), only 2, number of social organizations and ENVSCOR, proved insignificant, meaning that these 2 external indicator variables were not significant in explaining the variation across cluster groups

Results of the MANOVA analysis are presented in Table 3. From this analysis, one can see that the means of 4 external indicator attributes of the number of memberships in social organizations, ENVSCOR, summer dependency, and fall dependency were not significantly different across cluster groups. However, the overall test rejects that the vector of all external indicator attribute means are the same across cluster groups.

\section{Results}

Looking at Figure 1, two knees occur in the percent of total variation in all attributes accounted for by the clustering solution graph: 1 at 5 clusters and 1 at 8 clusters. Unfortunately, within FASTCLUS there is no method to test whether the 5 cluster solution is better than the 8 cluster solution. The 8 cluster solution appears better because $15.7 \%$ more variation is described by 8 clusters than 5 . Because this method is not definitive, qualitative judgements also count. Rosenburg and Turvey (1991) suggested that the appropriate number is simply the number that fulfills the objectives of the study. After looking at the means of the attributes across clusters, 8 clusters provide a better, more explicit set of rancher subgroups than 5 clusters.

Of the 24 attributes used to form the clusters, only 2 , the PASS objective and the percentage of income from the provision of recreation services, proved insignificant. Table 1 presents the means of the attributes by cluster and the significance test on each variable. Of the 12 external indicator attributes (Table 2), only 2 , number of social organizations and
ENVSCOR, proved insignificant, meaning that these 2 external indicator variables were not significant in explaining the variation across cluster groups

Results of the MANOVA analysis are presented in Table 3. From this analysis, one can see that the means of 4 external indicator attributes of the number of memberships in social organizations, ENVSCOR, summer dependency, and fall dependency were not significantly different across cluster groups. However, the overall test rejects that the vector of all external indicator attribute means are the same across cluster groups.

In summary, all groups rank consumptive objectives above profit maximizing objectives suggesting that all ranchers are economic satisficers with varying degrees of importance placed on earning potential from the ranch. In fact, all groups ranked the TRAD and FAMILY objectives as the first or second most important objectives (Table 1) and the PROFIT objective was ranked in the middle of the pack across all groups. From comments written in the margins of the returned surveys and subsequent follow-up telephone calls, many do not believe that earning an adequate return is possible given current market condi- 
Table 3. MANOVA results.

\begin{tabular}{lrr}
\hline \hline External Indicator Attributes & $\begin{array}{c}\text { Univariate } \\
\text { Probability }\end{array}$ & $\begin{array}{c}\text { Multivariate }^{1} \\
\text { Probability }^{2}\end{array}$ \\
\hline Age & 0.0001 \\
Social Organizations & (NS) 0.2460 \\
Production System & 0.0001 \\
Income & 0.0001 \\
History & 0.0001 \\
Deeded Acres & 0.0001 \\
Envscore & (NS) 0.7272 \\
Partscore & 0.0108 \\
Spring Dependency & 0.0189 \\
Summer Dependency & (NS) 0.1995 \\
Fall Dependency & (NS) 0.1306 \\
Winter Dependency & 0.008 \\
Percent Reduction & \\
25\% & 0.025 \\
50\% & 0.0006 \\
100\% & 0.0007 \\
Fee Increase & \\
\$2-\$5/AUM & (NS) 0.2259 \\
\$5-\$8/AUM & 0.0242 \\
\$8/AUM & 0.0079 \\
Eliminate Season & \\
Winter & 0.0008 \\
Spring & 0.0032 \\
Summer & 0.0423 \\
Fall & 0.0156 \\
Overall Test & \\
\hline
\end{tabular}

${ }^{1}$ Probability value for chi-square test. $\alpha<0.05$ reject the hypothesis that the mean value is the same across cluster groups. ${ }^{2}$ Probability value for Wilks' Lambda likelihood ratio test. $\alpha=0.05$ reject the hypothesis that the vector of means are is the same across all cluster groups.

tions. Therefore, instead of ranking the importance of this objective, some may have ranked the ability to earn a profit, thus offering some explanation as to why investment performance was ranked low by most groups. Naming cluster groups has been widely used within cluster analysis to aid in broadly identifying cluster groups (Bernhardt et al. 1996, Bartlett et al. 1989). To identify cluster groups in this analysis, these groups are given names that describe their central characteristics. These groups include small (diversified) family ranchers, working hobbyists, sheep herderranchers, medium (dependent) family ranchers, small hobbyist, retired hobbyist, trophy rancher, and corporate rancher. Their general characteristics are described below.

\section{Small Hobbyist}

Small hobbyists, $11.1 \%$ of respondents, have the lowest dependence on ranching and other on-ranch sources of income of any group. Most of their income comes from off-ranch jobs, but they are slightly more diversified into retirement income and investment income than the working hobbyists. This group is also highly educated with a large percentage of its members having graduate degrees. They also have the smallest herd size and smallest deeded acreage. They rank PROFIT the lowest of any group. This group has a low overall dependence on federal forage although they are not the lowest.

\section{Retired Hobbyist}

Retired hobbyists, $18 \%$ of respondents, are the most dependent on ranching and agriculture for income compared to the other 2 groups of hobbyists. In fact, their dependence on-ranch sources of income is $49.5 \%$, making the dependence line harder to draw. It may be more appropriate to classify this group as retired ranchers rather than retired hobbyists because it is possible they were once family ranchers who have scaled back their ranching operation in recent years substituting retirement income, investment income, and offranch jobs for the lost ranch income. Unfortunately, there are no data from this survey to support this claim. They also have the highest average age.

This group is characterized by a low dependence on ranching income and other on-ranch income sources and has the highest degree of dependence on off-ranch job income. They have a relatively small herd size, although they are the largest of the hobbyists, and own an average of 1,563

\section{Working Hobbyist}

deeded acres. While they have ranked the profit maximization objective high relative to the other groups, they still value consumptive uses above profit maximization. It appears that tradition motivates many in this group because the family tenure variable, HISTORY, is largest for this group (Table 2). This suggests that individuals in this group ranches to continue a business started by their family because they appreciate the consumptive value of ranching, not because they are supporting their family with the income. Overall, this is the youngest group and represents $15.4 \%$ of the ranchers responding.

\section{Trophy Rancher}

This group ranks the PROFIT objective very low yet they have very large herds, large deeded acreages, and high overall labor requirements. In fact, they hire twice as much labor as their family supplies. They also have the highest income of all the groups, but most of this income comes from off-ranch sources, particularly investment income. They are very willing to use business organization to reduce risk as evidenced by the fact that they are second to the last in terms of using the least risk reducing organization, sole proprietorship and most involved in LLC's limited liability corporations. Trophy ranchers are also the best educated with the largest percentage of 4 year college graduates and the second highest percentage of graduate school graduates. This group is also the least dependent on public forage sources. This group constitutes $6 \%$ of the ranchers responding. Although individuals in this group ranked the consumptive objectives low relative to the other groups, it appears that they are using ranching as a consumptive good. It appears that this group is independently wealthy and owns very large ranches for purposes other than generating income. It could be argued that these ranchers are practicing conspicuous consumption (Smith and Martin 1972). In other words, the value of owning just any ranch is less to them than the value of owning a very large, extensive, publicly visible ranch. Unfortunately, this objective was not represented in the choice set presented in the survey.

\section{Dependent Family Rancher}

This group has the highest dependence on ranching income and is the least diversified into other income sources. This group has very interesting objective rankings. They give the highest rank to all objectives, with the exception of the ENVIRO objective, across all clusters, yet 
they still rank PROFIT fifth. This suggests that this group feels very strongly about ranching as a way of life. In addition, this group feels the most trapped in ranching given its ranching skill set and is also the least educated. This group is organized into partnerships, both limited and general, more than any other group, however, most of the ranches in this category are organized as sole proprietorships. This group exhibits the highest debt load, but feels a low degree of financial stress. This group is also the least willing to participate in riparian conservation practices. This group contains $18.6 \%$ of the ranchers responding, making it the largest group.

\section{Diversified Family Rancher}

This group, $13.5 \%$ of respondents, has the smallest herd size of any group dependent on ranching income (Table 1). However, they are only slightly smaller than the dependent family ranch. The family label is given because of their relative dependence on family labor. This group also has the lowest income of any other group. The most striking difference between dependent and diversified family rancher groups is their degree of diversification. Diversified family ranchers are less dependent on ranch income and are more diversified into production of other agricultural commodities, forestry, and offranch jobs. Also, this group ranked the profit maximizing objective the second highest of all groups, suggesting a high degree of profit maximizing behavior. On the other hand, this group still ranks consumptive objectives higher than the profitmaximizing objective. Overall, this group uses business organization the least to reduce risk. On average, this group owns 4,765 deeded acres.

\section{Corporate Rancher}

This cluster, $13.1 \%$ of respondents, is highly dependent on ranching for income, has the largest herds, in terms of animal units, and large deeded acreages (second only to sheep herderranchers). This group also hires the second largest labor force. Interestingly, however, this group still holds consumptive objectives in high regard, and the INVEST objective is ranked again in the middle of the pack. The corporate label stems from the use of the sub-chapter $\mathrm{S}$ and sub-chapter $\mathrm{C}$ corporate status more than any other group. In addition, this group comes in second in the use of LLCslimited liability corporations. Interestingly, this group and the sheep herders are the most financially stressed of any other group. This is intuitively appeal-

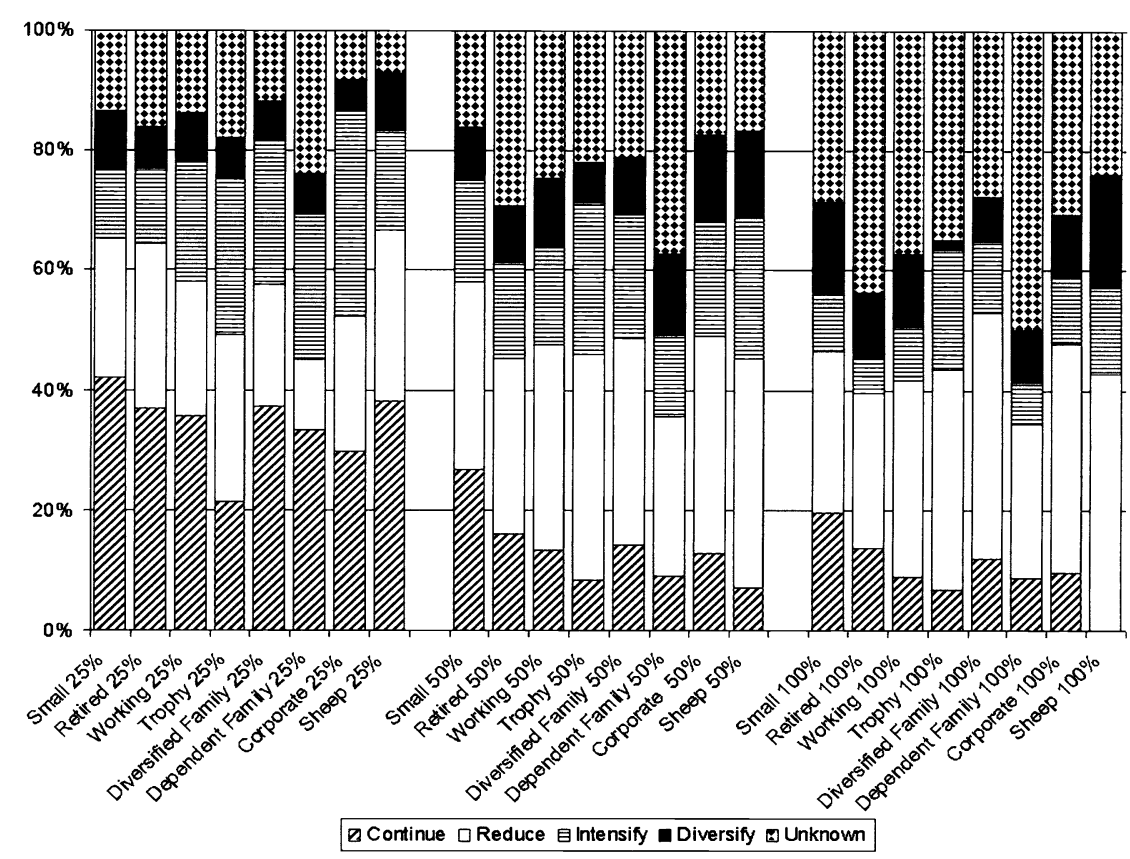

Fig. 3. Responses Response by group to percent reductions in AUM's.

ing as both may require large seasonal loans to pay their hired labor. While most of the other groups indicate that cow-calf operations are their mainstays, with the exception of sheep herder ranchers of course, this group contains a large number of cow-calf-yearling operations.

\section{Sheep HerderRanchers}

This group, $4.3 \%$ of respondents, is characterized by its dependence on sheep as its primary animal production system. This group has large herds and the largest deeded acreage holding. This group has the highest overall labor requirement, as would be expected given the nature of sheep herding, and hires the most labor. They have a very large percentage of 4 year college graduates. This group is highly dependent on ranching income. Also, this group indicated the highest willingness to participate in riparian conservation activities (Table 2). Finally, this group has the highest dependence on public grazing across all seasons.

\section{Policy Implications}

From the above results it appears that public land ranchers are very heterogeneous. Their motivations represent a continuum that varies from consumption of ranching as a good to profit. As a result, one-size-fits-all policies may prove disastrous for those ranchers dependent on ranching for their livelihood. To explore this idea further, respondents were presented a series of questions that asked how they would respond to 3 different percent reductions in permitted AUMs, 3 different increases in the grazing fee, and the elimination of each of 4 seasons of use. They were presented with 5 discrete response strategies. These strategies are:

1. Continue $=$ you think your current operation will work in the future or do not have the resources to change.

2. Reduce $=$ you will cut back on livestock production, pass operation down to the next generation, reduce your herd, or sell your ranch.

3. Intensify = you will intensify your use of private grazing land. Examples include purchasing or leasing more private land, increasing irrigated acres, improving forage, instituting a new grazing system, etc.

4. Diversify $=$ you will diversify your operation either on-ranch or offranch. Examples include pursuing more or better off-ranch employment, growing different crops for cash sale, offering ranch based recreation, or adding a new class of livestock.

5. Unknown $=$ you are not sure what you would do in the face of change.

These categories were developed using advice from peers and rancher focus groups. Although intensification includes characteristics more generally considered under extensification, or increasing the scale of an operation, the focus group participants felt that intensification more 


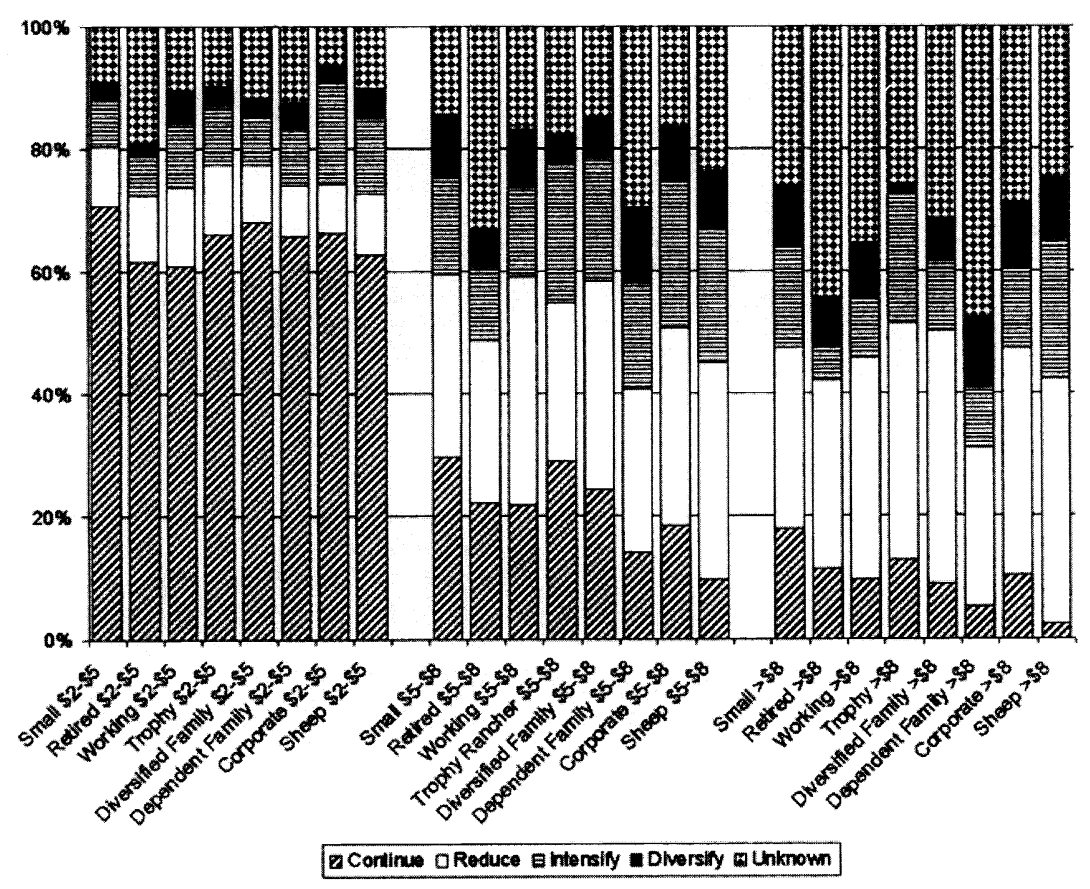

Fig. 4. Responses Response by group to changes in the grazing fee.

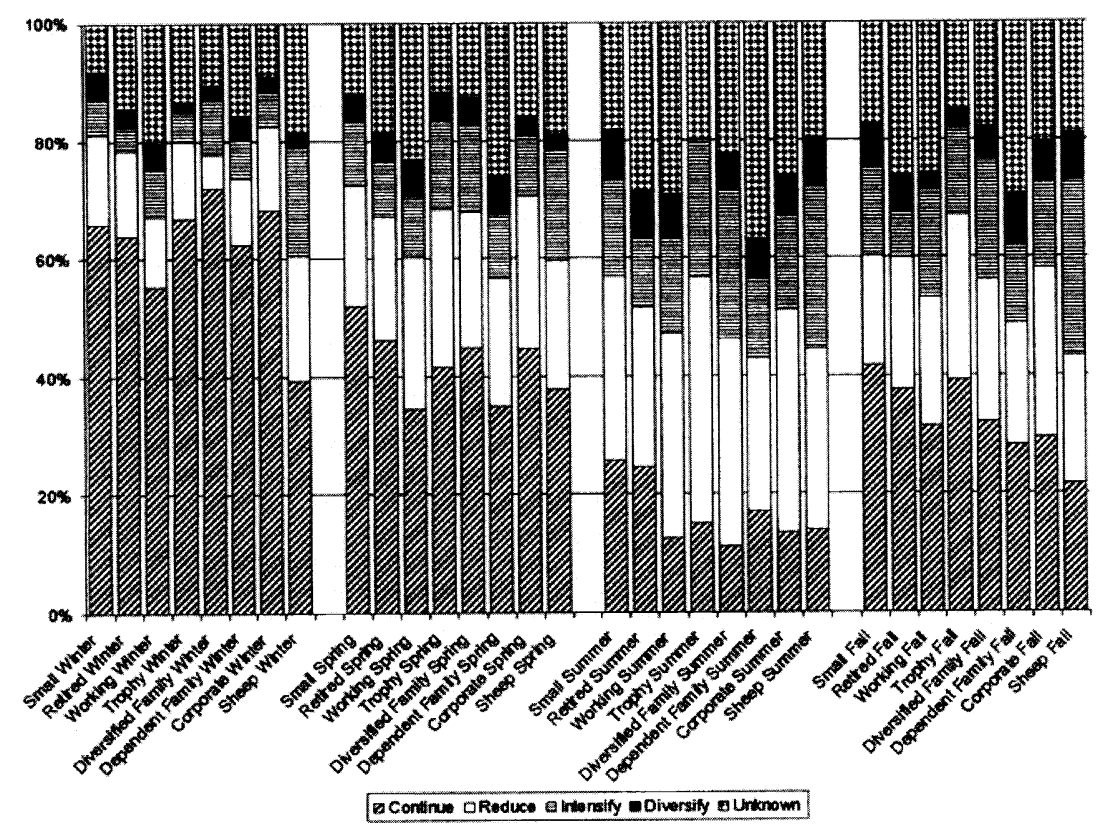

Fig. 5. Responses Response by group to elimination of a season of use.

appropriately described this choice. More specifically, in many locales across the West, extensification has become prohibitively expensive, and many in the focus groups felt that extensification would only be undertaken as a small step in the process of a larger intensification plan. Therefore, the above responses are assumed to constitute the entire choice set facing ranchers under the policy change scenarios. These 3 broad policy change scenarios and their corresponding levels were selected because all of these scenarios and levels of change have been discussed in the public land grazing policy debate that has developed in the last several decades.

Ranchers in the first scenario were asked how they would respond to percent reductions $(25 \%, 50 \%, 100 \%)$ in their permitted AUMs (Fig. 3). In the second scenario, ranchers were asked how they would respond to 3 increases in the grazing fee $\left(\$ 2-\$ 5, \$ 5-\$ 8\right.$, and $>\$ 8 \mathrm{AUM}^{-1}$ increase) over the current level (Fig. 4). Finally, ranchers were asked how they would respond to the elimination of winter, spring, surmer, or fall use (Fig. 5). The MANOVA analysis shows that the mean respon.e to these questions is significantly $\operatorname{dif}_{\text {. }}^{\prime}$ erent across clusters for all levels of a'i questions, except 1 , the response to th smallest change in the grazing fee (Table 3).

It is difficult to draw broad conclusions about the data presented in Figures 3, 4, and 5 . In fact, drawing broad conclusions defeats the purpose of this analysis. Instead, these figures indicate the percentage of individuals in that group that will undertake a given strategy in the face of policy change. Given the characteristics of a particular group of ranchers, their response can then be predicted. This information has direct applicability to economic impact modeling on the regional level by classifying ranchers and quantifying how they will react to policy changes.

With that said, some general conclusions do emerge. First, for a relatively small increase in the federal grazing fee, from $\$ 1.35 /$ AUM to $\$ 2-\$ 5 / A U M$, there is no significant difference between clusters (Table 3). Also, at this small level of change, the large majority of ranchers will continue their operations as is, absorbing the additional cost (Fig. 3). Another interesting result that emerges concerns selection of the diversification strategy. Across all scenarios and all levels, diversification is the least frequently selected strategy (Fig. 3, 4, and 5). By encouraging income diversification, the stability of those family ranches dependent on farm or ranch income could be increased in the face of policy uncertainty. In addition, as levels of change increase, the dependent family ranchers and the retired hobbyists select the unknown response more frequently. This degree of uncertainty deserves further examination. Perhaps the choice set does not fully reflect the strategies they face or they may feel they are simply backed into a corner with no hope for recovery in the face of such changes. The latter explanation may hold some merit for the dependent family ranchers because they ranked the SKILLS objective highest of any other group (Table 1). The SKILLS objective indicates feelings of being trapped in ranching because ranching is the only pro- 
Table 4. Private acreage by cluster as reported by respondents and extrapolated to the population.

\begin{tabular}{lcr}
\hline \hline Cluster & $\begin{array}{c}\text { Respondent } \\
\text { Private }\end{array}$ & $\begin{array}{c}\text { Westwide } \\
\text { Westwide }\end{array}$ \\
\hline Hobbyists & & \\
$\quad$ Small Hobbyist & 160,798 & $3,212,597$ \\
Retired Hobbyist & 461,071 & $9,211,778$ \\
Working Hobbyist & 251,698 & $5,028,696$ \\
Trophy Rancher & 701,409 & $14,013,512$ \\
Professionals & & \\
Diversified Family Rancher & 662,386 & $13,233,868$ \\
$\quad$ Dependent Family Rancher & 770,918 & $15,402,238$ \\
Corporate Rancher & $1,719,844$ & $34,360,914$ \\
$\quad$ Sheep Rancher & 653,349 & $13,053,317$ \\
Total & $5,381,473$ & $107,516,920$ \\
\hline
\end{tabular}

fession they feel qualified to pursue given their skill set. Finally, as the level of change increases, all groups move away from continuing as a strategy and move into reduction and intensification. However, no clear pattern emerges between groups concerning preferences for 1 particular strategy over another.

\section{Conclusions}

The groups emerging from this analysis represent a continuum of economic behavior ranging from consumption of ranching as a good to ranching for profit. Ranching for a profit is a difficult concept because even the dependent family and corporate ranchers value the consumption of ranching as a good. This fits with previous results that even large ranchers may act as economic satisficers, producing an income that is satisfactory, enough to pay the bills, while consuming ranching as a good (Smith and Martin 1972). These results also help to describe the heterogeneity of ranchers across the West by first grouping by socioeconomic and demographic attributes. Overall, it is interesting to note that hobbyists, those not dependent on ranching income, comprise $50.4 \%$ of all public land ranch operators in the West. This distinction is arbitrary and is made when the percent of income derived from on-ranch sources is below $50 \%$. All but 1 group, the retired hobbyists are well below this mark. Conversely, $49.6 \%$ of all public land ranchers in the West are dependent, and in most cases heavily dependent, on ranching for their income.

In terms of policy implications, the selection of the intensification strategy has implications for the environment and selection of this strategy bears closer inspection. It is widely accepted that ranching and cattle grazing are less intensive than commercial crop production in terms of water usage, labor inputs, and chemical usage (Skaggs et al. 1994). As ranchers are forced to move away from grazing because of federal grazing reductions, some ranchers, as indicated in Figures 3, 4, and 5, will intensify their agricultural operation on their private land. Likewise, ranchers may sub-divide and sell their ranch property to make up for the lost income caused by policy changes. Summing across all respondents and extrapolating to the entire population, public land ranchers control $14.21 \%$ of the total land base in the 11 western states (Table 4). The environmental impacts from the increased intensification need to be analyzed as well as the income impacts.

Currently, input/output models developed for rural areas in the West use ranch classifications based on ranch budgets developed by size classes. While this is acceptable during the development of the base model in software such as IMPLAN, these groups may not represent homogeneous groups when strictly divided by ranch size and when modeling reactions to policy changes. Instead, the clusters represented here could be used to map expenditure patterns in the face of policy changes across 8 distinct groups based on not only size, but other socioeconomic characteristics like income, income sources, motivations, and their stated preferences in the face of such changes. The use of this information would yield more accurate impact assessments because better information on rancher attributes and behavior are used.

\section{Literature Cited}

Aldenderfer, M.S. and R.K. Blashfield. 1984. Cluster Analysis. Sage Publications, Beverly Hills, Calif.

Bartlett, E.T., R.G. Taylor, J.R. McKean, and J.G. Hof. 1989. Motivation of Colorado ranchers with federal grazing allotments. J. Range Manage. 42:454-457.

Bernhardt, K. J., J.C. Allen, and G.A. Helmers. 1996. Using cluster analysis to classify farms for conventional/alternative systems research. Rev. Agr. Econ. 18:599-611.
Birkenfeld, A. 1994. Diversity and innovation adoption among Utah public land permittees. M.S. Thesis, Utah State Univ., Logan, Utah.

Biswas, B., J.R. Lacey, J.P. Workman, and F.H. Siddoway. 1984. Profit maximization as a management goal on southeastern Montana ranches. West. J. Agr. Econ. 9:186-194.

Council for Agricultural Science and Technology (CAST). 1996. Members: W.A. Laycock, D. Loper, F.W. Obermiller, L. Smith, S.R. Swanson, P.J. Urness, and M. Vavra. 1996. Grazing on public lands. Task force rep. no. 129.

Everitt, B. S. 1993. Cluster Analysis, Third Edition. Arnold a member of the Hodder Headline Group, London, England.

Fowler, J.M. and J.R. Gray. 1988. Rangeland economics in the arid West." In: Rangelands, $1^{\text {st }}$ ed., Bruce A. Buchanan (ed.). Albuquerque: Univ. of New Mexico Press.

Harper, W. M. and C. Eastman. 1980. An Evaluation of Goal Hierarchies for Small Farm Operators. Amer. J. Agr. Econ., 62:742-747.

Jain, A.K. and R. C. Dubes. 1988. Algorithms for Clustering Data. Prentice Hall, Englewood Cliffs, N.J.

Lorr, M. 1983. Cluster Analysis for Social Scientists. Jossey-Bass Publishers, San Francisco, Calif.

Power, T.M. 1996. Lost Landscapes and Failed Economies: a Search for Value of Place. Island Press, Covelo, Calif.

Romesburg, C.H. 1984. Cluster Analysis for Researchers. Lifetime Learning Publications, Belmont, Calif.

Rosenburg, A. and C.G. Turvey. 1991. Identifying Management Profiles of Ontario Swine Producers Through Cluster Analysis. Rev. Agr. Econ. 13:201-13.

Salant, P. and D.A. Dillman. 1994. How to Conduct Your Own Survey. John Wiley and Sons, Inc., New York, N.Y.

SAS Institute Inc. 1983. SAS Technical Report A-108, Cubic Clustering Criterion, SAS Institute Inc., Cary, N. C.

SAS Institute Inc. 1989. SAS/STAT User's Guide, Version 6, Fourth Ed., Vol. 1. SAS Institute Inc., Cary, N.C.

Skaggs, R.K., R.E. Kirksey, and W.M. Harper. 1994. Determinants and Implications of Post-CRP Land Use Decisions. J. Agr. and Res. Econ. 19:299-312.

Smith, A. H. and W.E. Martin. 1972. Socioeconomic Behavior of Cattle Ranchers, with Implications for Rural Community Development in the West. Amer. J. Agr. Econ. 54:217-225.

U.S. Department of Agriculture. 1993. Structural and Financial Characteristics of U.S. Farms, 1994. 19 $9^{\text {th }}$ Annual Family Farm Report to Congress, Washington, D.C., AIB-735.

Workman, J.P. 1986. Range Economics. Macmillan Publishing Co., New York, N.Y.

Young, K. D., and C. R. Shumway. 1991. Cow-Calf Producers' Perceived Profit Maximization Objective: A Logit Analysis. So. J. Agr. Econ. 23:129-36. 